\title{
5. DOCUMENTATION
}

(Committee of the Executive Committee)

PRESIDENT: J.-C. Pecker.

VICE-PRESIDENT: W. D. Heintz.

ORGANIZING COMmitTEE: F. Henn, J. Kleczek, A. Maxwell, I. S. Shcherbina-Samojlova, J. B. Sykes, G. A. Wilkins.

\section{FONCTIONNEMENT DE LA COMMISSION 5}

Lors de l'Assemblée Générale de Brighton, la Commission, à la demande du Secrétaire Général de l'UAI, a adopté de nouvelles règles de procédure; celles-ci ont été légèrement modifiées par la suite, pour lever certaines contradictions soulevées par les décisions diverses prises par la Commission à Sydney, ce en accord avec le Secrétaire Général. Les nouvelles règles sont les suivantes:

\section{Scope and Objectives}

Ascertainment of the relations between the needs of astronomers and the primary, secondary (current-awareness, abstracting and indexing) and tertiary (review) publications, in astronomy; improvement of the correspondence between these needs and publications. Determination and provision of desiderata in auxiliary matters such as subject classification, transliteration, and standardization of abbreviations and notations. Exchange and retrieval of data.

\section{Officers}

President and one Vice-President, the latter normally succeeding as President after two terms.* Organizing Committee of President (Chairman), Vice-President, Past President, and not more than four other members of the Commission, each elected for two terms, plus the Chairmen of the Working Groups.

\section{Working Groups}

Working Groups may be formed within the Commission or jointly with other bodies, to deal with any specific topic, but must be re-established at each General Assembly.

\section{Election of Officers}

Elections are held by vote of members (not consulting members) of the Commission, present at meetings during the General Assembly or voting by post in elections between General Assemblies. Candidates for election should usually be nominated through the President in the twelve months preceding the General Assembly, and voting should take place at the first meeting during the General Assembly, the results being transmitted for approval by the Executive Committee and (as regards President and Vice-President) by the General Assembly.

*Period between conclusions of successive General Assemblies. 


\section{Voting}

Voting in the Commission and the Organizing Committee is by simple majority of those taking part.

Depuis l'Assemblée Générale de 1973, deux membres ont été cooptés par la Commission, Mme L. Remy-Battiau et M. R. S. Dixon. Ces cooptations ont été approuvées par le Comité Exécutif de l'UAI.

Les Groupes de Travail ont activement poursuivi leur mission; les rapports de ces groupes sont publiés séparément: le rapport de G. A. Wilkins (Chairman, Working Group on Numerical Data) sera inclus dans le volume XVI A des Transactions de l'UAI, comme le présent rapport, le rapport de A. Maxwell (Chairman, Working Group on Editorial Policy) et celui de D. A. Kemp (Chairman, FID-IAU, Working Group on UDC 52) seront publiés dans le volume XVI B, dans la partie traditionnellement consacrée aux problèmes d'édition et au manuel de rédaction.

J'attire tout spécialement l'attention sur ce dernier rapport en raison de son caractère presque définitif; l'UDC est un système de classification qui semble actuellement particulièrement bien adapté à l'astronomie.

La Commission, consultée par correspondance à la requête du Comité Exécutif, a adressé, à la date du 19 juillet 1974, au Secrétaire Général de l'UAI, un rapport détaillé sur la politique des publications de l'UAI (voir ci-après).

Enfin, la Commission a été régulièrement représentée au sein de l'ICSU Abstracting Board et a coopéré, dans la mesure de ses moyens, aux activités de cet organisme.

\section{ACTIVITÉS DE L'ICSU AB}

Depuis l'Assemblée Générale de l'UAI en 1973, l'ICSU Abstracting Board s'est réuni à plusieurs reprises: Berlin (1974), Bruxelles (1975) et Washington (1976). L'UAI a été représentée régulièrement à ces réunions (c'est l'une des 6 unions scientifiques adhérentes), ainsi que les services tels que Astronomy and Astrophysics Abstracts, ou les journaux analytiques ou signalétiques (Physics Abstracts, Bulletin signalétique du CNRS) couvrant les activités scientifiques de l'UAI.

Ces réunions sont l'occasion de contacts personnels fructueux. Parmi les nombreux problèmes importants discutés figurent:

(1) La généralisation du système des microfiches.

(2) Les règles de 'tagging' et de 'flagging' des analyses bibliographiques (le 'flag' sert à identifier la nature d'un document - livre, thèse, rapport; le 'tag' à identifier les éléments du document titre, auteur, lieu, date d'édition, contenu ....).

(3) L'avenir des services analytiques et signalétiques et l'impact sur ces services de l'utilisation des ordinateurs, et des journaux dits 'synoptiques'.

(4) Les relations avec l'UNISIST (on notera les travaux de l'ISDS, International Serials Data System, avec lequel les travaux de la Commission 5 devraient garder une coordination efficace).

(5) Le transfert d'information scientifique vers les pays en voie de développement.

De plus, l'ICSU AB prépare, avec l'aide de la Commission 5, un opuscule sur les services analytiques et signalétiques concernant l'astronomie. L'ICSU AB édite désormais ses rapports annuels; les membres de la Commission intéressés peuvent se les procurer au secrétariat de l'ICSU AB, 17 rue Mirabeau, 75016 Paris, France.

\section{AUTRES ACTIVITÉS BIBLIOGRAPHIQUES}

Dr. I. Shcherbina-Samojlova reports as follows: "Apart from the three issues of the Referativny Zhurnal (Astronomy, Space Exploration, and Geodesy and Aerial Survey), the Viniti Astronomy department publishes annual collections of papers of a review nature (Itogi nauki $\mathbf{i}$ techniki), in three series corresponding to the issue of the Referativny Zhurnal. Besides, we are 
compiling a thesaurus designed for automatic retrieval of astronomical information and are working in the field of astronomical technology".

Dr. Fricke et Miss F. Henn m'informent des activités de leur groupe: "Astronomy and Astrophysics Abstracts has continued to be published regularly in semi-annual volumes. Volume 13 covering the literature of the period January to June 1975 has appeared in November 1975, and the following two volumes to appear in 1976 will cover the period from July 1975 to June 1976. In addition, an Index Volume including a complete Author and Subject Index for the volumes 1 to 10 will appear in 1976."

\section{PUBLICATIONS DE L'UAI}

Le Comité Exécutif de l'UAI se préoccupe à juste titre du prix élevé des publications de l'UAI, qui les rendent difficiles d'accès aux jeunes astronomes, comme aux astronomes des pays en voie de développement. Bien qu'aucun changement dramatique ne soit envisagé, le Comité Exécutif s'est demandé si les possibilités suivantes ne devraient pas être explorées:

(a) Création par l'UAI d'une maison d'édition (IAU Publishing House).

(b) Recherche d'un éditeur moins coûteux que l'éditeur actuel;

(c) Publication bon marché grâce aux techniques 'offset'.

La Commission, consultée par le Secrétaire Général, a pu présenter un rapport très détaillé au Comité Exécutif. Les membres de la Commission divergent évidemment grandement dans leur appréciation; statistiquement, ils sont opposés a la solution (a) envisagée sous une forme classique; sceptiques quant aux chances de la solution (b) et plutôt favorables à la solution (c), bien qu'elle ne soit sans doute rentable que si l'UAI est son propre éditeur, et que de toutes façons, elle n'augmente guère le volume des ventes. Les membres de la Commission ont fait de nombreuses suggestions, telles que les suivantes:

- Prélèvement sur les droits d'inscription à un symposium d'une somme affectée aux publications (Dr. Koch, Director, American Institute of Physics, consulté par J. C. Pecker, lors d'une réunion de l'ICSU $\mathrm{AB}$ ).

- Vente d'exemplaires brochés à prix très réduit, à certaines catégories d'astronomes; amélioration de la publicité relative à ces ventes spéciales.

- Participation technique des presses nationales intéressées à la production des volumes des symposiums tenus dans divers pays (Pecker, Thomas, Président Commission 36, 1970-73).

- Production d'une revue bi- ou tri-mestrielle, qui contiendrait toutes les communications aux symposiums de l'UAI (A. Beer, après consultation avec A. Steel, Pergamon Press).

- Publication des communications aux symposiums de l'UAI dans des revues existantes, complétée par un court rapport bibliographique (environ 25 pages) par symposium (Wilkins, et lettre de Minnis, Secrétaire Général de l'URSI, à Wilkins).

- Publication de séries d'articles, chaque article en fascicule séparé et numéroté, à très bon marché, à partir des documents fournis par l'auteur (Kemp). Un index complet serait publié séparément.

- Organisation d'un Service d'Edition pour l'ensemble des unions de l'ICSU; l'aide de l'UNESCO pourrait être envisagée pour aider les pays en voie de développement (Wilkins et Minnis).

Les trois dernières suggestions sont d'un intérêt particulier et rencontrent peut-être moins d'objections que les autres. Mais une mise au point rigoureuse est nécessaire.

Nous devons noter l'importance, soulignée par plusieurs membres de la Commission, que revêtent ces questions pour la communauté scientifique dans son ensemble. Les articles suivants ont été cités comme particulièrement significatifs:

Foskett, D. J.: 1972, 'Some Sociological Aspects of Formal Systems for the Communication of Knowledge'. Chernyi, A. I.: 'Problems of Information Science', Moscow.

All-Union Institute for Scientific and Technical Information, 1972 (FID \# 478).

Hall, J.: 1974, 'Science Journals in a Prices Jungle', Nature 247, 417.

Walsh, J.: 1974 'Journals: Photocopying is not the Only Problem', Science 183, 1274. 
On notera que les éditeurs réagissent souvent par la voie légale contre l'utilisation systématique des photocopies, conséquence du prix élevé des publications; ainsi cela fut-il le cas récemment en France (voir par exemple Le Figaro, 30 janvier 1974, et 24 juillet 1974, sous la signature J. J.).

\section{DIVERS}

\section{Rare Astronomical Books (information transmitted by C. Bain.)}

"Miss Judith Lola, Librarian at the Yerkes Observatory of the University of Chicago at Williams Bay, Wisconsin, is gathering information on holdings of rare astronomical books in North American Libraries. This activity is a project of the Physics-Astronomy-Mathematics Division of the Special Libraries Association.

For the present, Miss Lola is simply building a file of location information and will fill requests for such information. Eventually a union list of holdings will be published, and it is expected that contributing libraries will be able to purchase a copy of the list at a reduced fee.

The list will include books published before 1800. Librarians and others who have information to contribute should send their entries in any format to Miss Judith Lola, Yerkes Observatory, Williams Bay, Wisconsin 53191."

\section{Activités des Associations de Bibliothécaires}

International Federation of Libraries Association, Special libraries section, Astronomical and Geophysical Libraries Subsection, chairman: Giovanna Grassi Conti. In the U.S.A. Special Libraries Association, Physics, Astronomy, Mathematics Division, chairman: Virginia van Brunt.

Les bibliothécaires des institutions astronomiques, membres ou membres consultants de la Commission 5, ont accompli un travail considérable, dont la Commission a constamment été tenue informée.

(1) Parmi les activités de l'IFLA astronomical and geophysical libraries subsection, il est important de noter la compilation des 'ouvrages astronomiques de base' en diverses langues; à noter l'exemple-test de la compilation de Bibliography of Basic Books in Astronomy (English Language), faite par M. R. A. Seal (University of Virginia Library, Charlottesville, U.S.A.). On doit considérer cette tâche comme essentielle, dans l'avenir, pour les autres langues que l'anglais; comme le projet 'Contretype' (voir Commission de l'Enseignement de l'Astronomie), ce travail est d'une importance primordiale pour les pays en voie de développement aussi bien que pour faciliter, dans les pays développés, la documentation des universités ou institutions isolées. Tous les astronomes compétents sont instamment priés de prendre contact avec Mme Grassi Conti à ce sujet.

On notera aussi des activités liées à l'histoire de l'Astronomie (voir rapport de la Commission 41 ).

(2) Aux U.S.A. (communiqué par Mme C. A. Bain), on notera que: 'In June 1975, the Physics-Astronomy-Mathematics Division was made a full division of the Special Libraries association. It no longer has provisional status. It has now a membership of well over 100 members but of course, not all of them are working with the astronomical literature. Work is continuing on the Union List of Astronomical Serials in North America and the Union List of Rare Astronomical Books in North American Libraries. Our plans for organizing the exchange of surplus astronomical materials have not advanced very far. We will continue to work on this problem and in the meantime we will use our Division's Bulletin to advertise our wants and our surplus publications.

The Bulletin of the Physics-Astronomy-Mathematics Division of the Special Libraries Association is issued quarterly in September, December, March and May, and the cost to non-members is $\$ 2.00$ per year.

Anyone wishing a subscription to this publication should contact Mr. R. A. Seal, Editor at the Science Technology Information Center, Clark Hall, University of Virginia, Charlottesville, Va. 22901. 
Mrs Bain adds that it seems highly desirable for IAU "to encourage the publication of a new edition of the International Physics and Astronomy Directory, 1969-70, published by W. A. Benjamin, Inc., New York, 1969". Je dois ici rappeler les efforts permanents de la Commission 5 pour réaliser un ouvrage de cette nature, aussi peu déformé que possible par les perspectives nationales de ses auteurs.

\title{
III. Priorités
}

Afin de fournir les axes principaux des discussions de la Commission au cours de l'Assemblée Générale de Grenoble, et à la suite des échanges de correspondance que j'ai pu avoir avec les membres et consultants de la Commission 5 , on peut dire que les problèmes les plus urgents sont actuellement:

(a) Le problème du coât des publications, et notamment celles de l'UAI, et la nécessité, corrélativement, d'explorer les techniques nouvelles (microfiches etc....) de diffusion des connaissances.

(b) L'adoption des recommandations du Groupe de Travail sur la Classification Décimale Universelle (UDC) tant par les éditeurs que par les bibliothèques.

(c) Les moyens d'amener les auteurs à suivre du mieux possible les indications du manuel de rédaction du CDU (UDC) pour le choix des mots-clefs, et la présentation de leurs articles.

Les autres problèmes urgents sont couverts par les activités des Groupes de Travail, notamment en ce qui concerne la révision nécessaire du manuel de rédaction de l'UAI (Numerical Data Working Group; Editorial Policy Working Group). En raison de l'importance de ces questions, elles seront couvertes par des rapports séparés publiés par le Secrétariat Général de l'UAI dans les volumes A et B des Transactions.

Le Groupe de Travail sur les Données Numériques a suscité l'organisation d'un colloque de

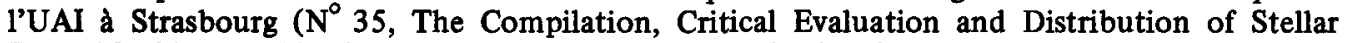
Data, 19-21 Août 1976) dont les travaux seront publiés séparément.

\author{
J.-C. PECKER \\ Président de la Commission
}

\section{REPORT OF WORKING GROUP ON NUMERICAL DATA FOR 1973-75}

MEMBERS: M. S. Davis, R. H. Garstang, B. Hauck, C. O. R. Jaschek, J. Jung, Z Kadla, K. I. Kellermann, T. Lederle, B. Morando, J.-C. Pecker, L. Perek, G. A. Wilkins (Chairman).

Arrangements were made for a meeting of the Group at Herstmonceux in 1974 April, but it was not held as it was found that too few of the members were able to attend. However, Jung and Wilkins met to draft the initial proposals for an IAU Colloquium on 'the compilation, critical evaluation and distribution of stellar data'. This proposal was accepted by the IAU Executive Committee and the Colloquium will be held at Strasbourg on 19-21 August 1976; Jaschek is acting as secretary of both the scientific and local organising committees. The level of Group activity has, otherwise, been low, although the individual members have been active in their own fields.

The Stellar Data Centre of the University Observatory at Strasbourg has continued to both receive and distribute data and has issued four Information Bulletins (Nos. 5-9) since the meetings in August 1973. These Bulletins give details of the catalogues and of other data and bibliographical services available from the Centre, and it also contains information about catalogues in preparation elsewhere and about related matters. A list of the star catalogues that were available at 1974 February has been published in Astron. Astrophys. Suppl. 16, 289, 1974.

The International Information Bureau on Astronomical Ephemerides at the Bureau des Longitudes in Paris, has now issued a total of 111 cards giving information about ephemerides and catalogues that are available from six institutions that have indicated their willingness to make copies of their data available to others. 
The Editors of Astronomy and Astrophysics Supplements have announced, on page 1 of volume 18, that they are prepared to publish notices about the existence of magnetic tapes containing astrophysical data already published or new data whose publication is not contemplated. The notices and the tapes will be examined by referees, and a copy of each tape will be held at Strasbourg.

The proceedings of a symposium on 'the collection and analyses of astrophysical data', which was held at Charlottesville, U.S.A., in November 1972 have been published in Astron. Astrophys. Suppl. 15, 321, 1974. Many of the papers are concerned with radio-astronomical techniques, but some papers are of more general interest.

The data activities of other international organisations are of relevance to astronomy and the following points may be noticed.

The ICSU Committee on Data for Science and Technology (CODATA) is widening the scope of its activities to cover the geosciences, including astronomy, the biosciences, and engineering, as well as the fundamental data of physics and chemistry, which have been its prime concern until recently. Wilkins is the IAU delegate to CODATA and is currently Chairman of its Advisory Panel on the Geosciences.

The Federation of Astronomical and Geophysical Services (FAGS) continued to allocate grants made by ICSU and UNESCO in support of the permanent data services of common interest to IAU, IUGG and URSI. The officers are normally appointed from each of the Unions in turn; Wilkins was appointed as Secretary at the beginning of 1975, and Enslin has taken his place as IAU delegate on the Council; the other IAU delegate is Contopoulos.

The ICSU Panel on World Data Centres continues to advise and coordinate the work of the World Data Centres that were originally set up in connection with the IGY. These data centres are funded by the countries in which they lie. They act primarily as 'data banks', in contrast to the services in FAGS, which act primarily as 'data analysis centres'; they hold mainly data about the Earth and the Sun. The Chairman of the Panel is Perek.

Representatives of CODATA, FAGS and the Panel on WDCs met at Grenoble in August 1975, during the General Assembly of IUGG, to exchange information and to discuss the relationships between their activities. The discussion confirmed that the three organisations should remain separate but that the liaison between them should be developed further. The publications of CODATA and the Panel's Guide to International Data Exchange contain material of interest to astronomers.

The ICSU Abstracting Board (ICSU AB) is considering, jointly with CODATA, the questions of how best to indicate in an abstract journal the inclusion of data in original papers. Different systems of 'tagging' and 'flagging' are already in use, and it is hoped that a standard system can be devised and that it will be adopted widely.

Further details of the activities of ICSU AB, FAGS and CODATA are given in IAU Information Bulletin No. 33, pp. 34-38, January 1975.

G. A. WILKINS

Chairman of the Working Group 